Michał Kubiak

ORCID: 0000-0002-4231-8071

Uniwersytet Gdański

\title{
Gminne rady seniorów z perspektywy lokalnej polityki senioralnej
}

DOI: 10.19195/1643-0328.25.7

Słowa kluczowe: polityka senioralna, gminne rady seniorów

\section{Wprowadzenie}

W ramach określonych obszarów polityki samorządów lokalnych wobec ludzi starszych można odnaleźć wiele działań podobnych, nacechowanych jednak indywidualną specyfiką i różną dynamiką. Do takich należą decyzje ze strony samorządów o powołaniu gminnych rad seniorów. Celem artykułu jest zbadanie zasad funkcjonowania gminnych rad seniorów ze szczególnym uwzględnieniem istniejących w województwie pomorskim. Pierwsza część pracy dotyczy ujęcia systemowego rad seniorów, a kolejna skupia się na analizie ich struktury i działalności. W pracy ukazano najważniejsze podobieństwa i różnice w funkcjonowaniu rad seniorów, a także przykłady decyzji w wymiarze praktycznym.

\section{Partycypacja seniorów w kontekście polityki senioralnej}

Obserwowany w Polsce proces starzenia się populacji sprzyja akcentowaniu potrzeb i roli odgrywanej w społeczeństwie przez seniorów. Zarówno rząd, jak i samorządy różnych szczebli opracowują poświęcone tej materii dokumenty. Przybierają one różne formy od strategii polityki senioralnej, po konkretne programy działań na rzecz osób starszych i lepszej jakości ich życia. W wielu dużych miastach działają wyspecjalizowane centra aktywizacji seniorów, a samorządy starają się dostosowywać przestrzeń publiczną do potrzeb seniorów, wspierając m.in. działania organizacji pozarządowych. Jednak specyfika procesu starzenia się ludności sprawia, że prowadzenie polityki senioralnej staje się coraz istotniejszym wyzwaniem, tak w skali państwa, jak na poziomie lokalnym. Politykę senioralną definiuje się jako „ogół administracji publicznej oraz innych organizacji i in- 
stytucji, które realizują zadania i inicjatywy kształtujące warunki godnego i zdrowego starzenia się"1. Jednym z jej celów strategicznych jest wspieranie i zapewnianie możliwości aktywnego starzenia się w zdrowiu oraz możliwości prowadzenia samodzielnego i satysfakcjonującego życia. Wychodzi się z założenia, że seniorzy działający w przestrzeni publicznej zapewniają sobie zaspokojenie potrzeb, takich jak kontakty z innymi, wymiana informacji czy motywacja do aktywności.

Zgodnie z koncepcją aktywnego i zdrowego starzenia się, oprócz zasadniczych jej filarów, takich jak: zdrowie oraz bezpieczeństwo (wymiar finansowy, emocjonalny i inne), wskazuje się również na partycypację rozumianą jako uczestnictwo i zaangażowanie seniorów w życie społeczne. Ta ostatnia, przyjmując różne formy, ma przekładać się na kształtowanie otaczającej rzeczywistości przez seniorów zgodne z ich oczekiwaniami mobilizowanie ich kapitału społecznego ${ }^{2}$.

Jedną z podstawowych form partycypacji obywatelskiej jest udział w działaniach różnego rodzaju organizacji, rozumiany w kategoriach zarówno członkostwa, jak i społecznej pracy w ramach danej struktury. Jak wynika z badań, odsetek osób starszych zaangażowanych w działania na rzecz społeczności lokalnej (gminy, osiedla, miejscowości, w najbliższym sąsiedztwie) oscyluje wokół 15,5\% i obniża się wraz z wiekiem (zob. tabela 1).

Tabela 1. Zaangażowanie osób starszych w działania na rzecz społeczności lokalnej

\begin{tabular}{l|c}
\hline Przedział wieku & Odsetek zaangażowanych \\
\hline $60-64$ & $15,5 \%$ \\
\hline $65-69$ & $13 \%$ \\
\hline $70-74$ & $10 \%$ \\
\hline $75-79$ & $8,2 \%$ \\
\hline $80+$ & $6 \%$ \\
\hline
\end{tabular}

Źródło: J. Czapiński, P. Błędowski, Aktywność społeczna osób starszych w kontekście percepcji Polaków. Diagnoza społeczna 2013. Raport tematyczny, Warszawa 2014, s. 68.

Według reprezentatywnych badań gdańskich seniorów (65+) tylko 12,5\% osób starszych należało do organizacji społecznych (częściej mężczyźni niż kobiety, a także ludzie lepiej wykształceni). Natomiast w nieodpłatnie podejmowanych oddolnie działaniach

1 Założenia Długofalowej Polityki Senioralnej w Polsce 2014-2020, załącznik do uchwały nr 238 Rady Ministrów z 24 grudnia 2013 r., M.P. z 4 lutego (poz. 118); ustawa z 26 października 2015 r. o osobach starszych, Dz.U. z 2015, poz. 1705.

2 Kierunek prowadzenia działań w zakresie tworzenia mechanizmów włączania osób starszych w procesy decyzyjne zaznacza się m.in. w Rządowym Programie na rzecz Aktywności Osób Starszych na lata 2014-2020 i promowaniu w jego ramach partycypacyjnego udziału seniorów w życiu publicznym (Priorytet III: Partycypacja społeczna osób starszych - 20\%, czyli 71 projektów w 2017 r.) oraz w Załączniku do projektu uchwały Rady Ministrów w sprawie przyjęcia dokumentu Polityka społeczna wobec osób starszych 2030. Bezpieczeństwo - Uczestnictwo - Solidarność, MRPiPS, Warszawa 2018 (część III.2: Uczestnictwo w życiu społecznym oraz wspieranie wszelkich form aktywności obywatelskiej, społecznej, kulturalnej, artystycznej, sportowej i religijnej). 
społecznych brało udział zaledwie 13,7\% badanych ${ }^{3}$. Zatem formalnie udział seniorów kształtuje się raczej na niskim poziomie. Wiadomo też, że wyższemu poziomowi integracji społecznej osób starszych i aktywności sprzyjają: młodszy wiek (największe możliwości aktywizacji w pierwszej fazie starości), wyższe wykształcenie, dobra sytuacja materialna, dobry stan zdrowia i sprawność, a także posiadanie małżonka (partnera) ${ }^{4}$. Jednak ok. 43\% seniorów pomaga swoim sąsiadom, co pokazuje, że jest to grupa mająca dość duży potencjał ${ }^{5}$. Ludzie starsi mniej angażują się w sprawy większej społeczności (np. miasta), a bardziej w sprawy bezpośrednio dotyczące ich codzienności i życia na konkretnym osie$\mathrm{dlu}^{6}$. Potwierdzają to badania zaangażowanych publicznie seniorów ${ }^{7}$, które prowadzą do wniosku, że wykorzystują oni swój potencjał przede wszystkim w najbliższym otoczeniu (rodzinie, sąsiedztwie, osiedlu). Jednocześnie jeśli istnieje bardzo silna zależność między przynależnością i aktywnym uczestniczeniem $\mathrm{w}$ organizacji a poziomem wykształcenia, to można mieć nadzieję, że aktywność wykraczająca poza najbliższe środowisko będzie rosła w kolejnych, coraz lepiej wykształconych generacjach seniorów ${ }^{8}$. Można dodać, że lepiej wykształceni seniorzy wykazują też wyższy poziom zainteresowania działaniami władz w gminie ${ }^{9}$. Zatem wydaje się, że w przyszłości można oczekiwać również większego zaangażowania osób starszych w proces partycypacji obywatelskiej rozumianej jako „zdolność do generowania działań lokalnych, które prowadzą do realizacji potrzeb i interesów społecznych"10.

\section{Rady seniorów - podstawy prawne}

Zaangażowanie ludzi starszych w życie społeczne przyjmuje różne formy, poczynając m.in. od klubów seniora, poprzez uniwersytety trzeciego wieku (UTW), Obywatelski Parlament Seniorów ${ }^{11}$, po rozwijające się od niedawna na poziomie lokalnym rady seniorów. Dzięki nim reprezentacje osób starszych mogą uczestniczyć w gremiach samo-

${ }^{3}$ P. Czekanowski, J. Załęcki, M. Brosz, Gdańska starość. Portret socjologiczny mieszkańców Gdańska w wieku 65+, Gdańsk 2013, s. 110.

${ }^{4}$ Ibidem, s. 130-135.

5 A. Buczyńska, P. Buczyński, Miejski model aktywności społecznej seniorów, Gdańsk 2013, s. 14-15.

6 A. Olech, Wprowadzenie, [w:] Dyktat czy uczestnictwo? Diagnoza partycypacji publicznej w Polsce, red. A. Olech, Warszawa 2012, s. 5.

7 S. Grotowska, Seniorzy w przestrzeni publicznej: kapitał społeczny uczestników wspólnot, ruchów i stowarzyszeń katolickich, Kraków 2011, s. 236.

${ }^{8}$ J. Czapiński, P. Błędowski, Aktywność społeczna osób starszych w kontekście percepcji Polaków. Diagnoza społeczna 2013. Raport tematyczny, Warszawa 2014, s. 69.

9 U. Abłażewicz-Górnicka, E. Krakowska, Partycypacja obywatelska, [w:] Seniorzy partycypuja, red. K. Sztop-Rutkowska, Białystok 2014, s. 81-82.

10 P. Weryński, Wzory uczestnictwa obywatelskiego Polaków, Warszawa 2010, s. 108.

11 „Obywatelski Parlament Seniorów jest oddolną, samorządną organizacją środowisk senioralnych powołaną dla reprezentacji, rzecznictwa interesów, prowadzenia dialogu i tworzenia płaszczyzny współpracy z parlamentem i rządem w kreowaniu polityki senioralnej w Polsce" — Regulamin OPS, http://parlamentseniorow.pl/wp-content/uploads/2017/11/Regulamin_OPS_II_kadencji_wersja_uchwalona_3_pazdziernika_2016.pdf (dostęp: 12.04.2018). 
rządów lokalnych i innych instytucji oraz wpływać na podejmowane przez nie decyzje. Szczególne nadzieje wiązane są z gminnymi radami seniorów, których funkcjonowanie w zamyśle ma przekładać się na większą skalę rzeczywistego wpływu na realizację interesów starszych pokoleń na poziomie lokalnym (podobne instytucje z powodzeniem istnieją w wielu państwach, a ich głównym zadaniem jest pośredniczenie i opiniowanie) ${ }^{12}$.

Uzasadnieniem wprowadzenia gminnych rad seniorów w Polsce jest coraz większa liczba osób starszych oraz rosnący poziom ich aktywności na różnych polach. Funkcjonowanie gminnych rad seniorów ma pozwolić na bardziej skuteczne przedstawianie oczekiwań i potrzeb osób starszych władzom lokalnym. Ujęcie rad seniorów w zapisie ustawowym jest też odpowiedzią na stojące przed władzami wyzwanie wiążące się z koniecznością aktywizacji tej systematycznie powiększającej się grupy najstarszych mieszkańców ${ }^{13}$.

Gminne rady seniorów w Polsce powstają na mocy nowelizacji ustawy o samorządzie gminnym (uosg) ${ }^{14} \mathrm{z} 11$ października 2013 r. (weszła w życie 30 listopada) ${ }^{15}$ i funkcjonują w oparciu o dodany artykuł 5 c ust. 2 i $5^{16}$. Ustawa unormowała nieusankcjonowaną wcześniej możliwość tworzenia w samorządach gminnych rad seniorów - instytucje takie powstawały już wcześniej, lecz na innych zasadach ${ }^{17}$ (najwcześniej w kilku dużych miastach $\mathrm{w}$ kraju $)^{18}$. Zgodnie z nowymi przepisami podstawy prawne umożliwiają praktyczne popularyzowanie idei przedstawicielstwa seniorów przy organach samorządu terytorialnego. Na mocy art. 5c ust. 2 uosg rada gminy, z własnej inicjatywy lub na wniosek zainteresowanych środowisk, może utworzyć gminną radę seniorów. Zatem organem właściwym do powołania gminnej rady seniorów jest (wyłącznie) rada gminy,

12 Np. w Danii, Austrii, Finlandii, Włoszech, Niemczech, USA; w Finlandii ponad 90\% osób w wieku 65+ mieszka w społeczności, w której przy władzach działa rada seniorów; w Niemczech lokalne rady seniorów funkcjonują już od lat 70. XX w. (obecnie ok. 1200) - A. Fiedotow, ABC Rad Seniorów, „Polityka Senioralna" 2017, nr 4, s. 7.

13 Uzasadnienie do projektu ustawy o zmianie ustawy o samorządzie gminnym, Sejm VII kad., druk nr 1572, http://www.sejm.gov.pl/Sejm7.nsf/druk.xsp?nr=1572 (dostęp: 12.04.2018).

14 Ustawa z 8 marca o samorządzie gminnym, t.j. Dz.U. z 2017, poz. 1875.

15 Ustawa z 21 października 2013 r. o zmianie ustawy o samorządzie gminnym, Dz.U. z 2013, poz. 1318.

16 Opis procesu ustawodawczego i jego przebieg zob. szerzej: M. Augustyniak et al., Gminne rady seniorów - wykładnia przepisów i efekty ich stosowania. Wzory i schematy działań, Warszawa 2016, s. 24-53.

17 Przed wprowadzeniem zapisu ustawowego powoływano w Polsce rady seniorów - w większości przy organie wykonawczym (wójcie, burmistrzu lub prezydencie) na mocy jego zarządzenia. W ich skład powoływano głównie przedstawicieli instytucji (OPS, urzędu gminy) i organizacji działających na rzecz osób starszych - K. Starzyk, Co gminom po radach seniorów, co seniorom po radach?, „Instytut Idei” 2014, nr 7, s. 76-79.

18 Jako pierwsza w Polsce powstała Rada (do spraw) Seniorów w Gdyni w 2004 r. (w jej skład weszli przedstawiciele organizacji i środowisk działających na rzecz seniorów oraz reprezentanci Prezydenta Miasta); Gdańską Radę (do spraw) Seniorów powołał Prezydent Gdańska, jako organ konsultacyjno-doradczy (załącznik do zarządzenia nr 1348/07 Prezydenta Miasta Gdańska z 10 października 2007 r., w sprawie powołania Gdańskiej Rady Seniorów i nadania jej regulaminu); w Poznaniu Miejską Radę Seniorów powołano na mocy Uchwały Rady Miasta nr XXIV/228/V2007 z 25 października 2007 r., z funkcją reprezentowania interesów osób starszych wobec władz miasta (15 osób w wieku 60+ wyznaczanych przez organizacje pozarządowe działające na rzecz osób starszych, Prezydenta Miasta i Radę Miasta Poznania). 
a utworzenie tej pierwszej następuje na podstawie uchwały wraz z uzasadnieniem i statutem (formalna decyzja o powołaniu — przyjęcie uchwały rady gminy). Jeśli mamy do czynienia ze ścieżką powstawania rady seniorów na wniosek zainteresowanych środowisk, to wówczas rada gminy jest zobowiązana do jego rozpatrzenia, ale nie jest nim zobligowana. Przewiduje się także możliwość utworzenia rady seniorów jednostki pomocniczej gminy (np. sołectwa, osiedla, dzielnicy) - wymaga to jednak odpowiedniego zapisu w jej statucie ${ }^{19}$.

Według zapisu ustawowego gminne rady seniorów pełnią funkcje konsultacyjne (możliwość opiniowania lokalnych strategii, programów rozwoju, projektów uchwał podejmowanych przedsięwzięć czy inwestycji), doradcze (możliwość zgłaszania uwag i sugestii władzom gminy), a także inicjatywną. Mogą zgłaszać opracowane we własnym gronie rozwiązania i propozycje działań na rzecz osób starszych (i upowszechniać informacje). W ten sposób pojawia się większa szansa na zaangażowanie seniorów w sferę obywatelskiej aktywności - jest to rola szczególnie akcentowana w literaturze ${ }^{20}$.

Nie ulega wątpliwości, że funkcjonowanie rad seniorów w dużej mierze jest determinowane składem osobowym, dlatego ważne jest, z jakich środowisk rekrutują się reprezentanci starszego pokolenia w gminie. Zgodnie $\mathrm{z}$ prawem gminna rada seniorów składa się z przedstawicieli osób starszych oraz przedstawicieli podmiotów działających na ich rzecz (w szczególności organizacji pozarządowych oraz podmiotów prowadzących uniwersytety trzeciego wieku). Zarówno tryb wyboru członków rady seniorów, jak i zasady jej działania powinny być dokładnie określone w statucie - nadawanym jej przez organ stanowiący gminy.

Najpopularniejszym modelem tworzenia rad seniorów jest delegowanie przedstawicieli działających w gminie organizacji senioralnych. Zazwyczaj wójt, burmistrz lub prezydent miasta zaprasza konkretne organizacje do wystawienia swoich kandydatów. Przeważnie w statutach znajduje się zapis dotyczący parytetu osób - przedstawicieli rady gminy, burmistrza (lub prezydenta czy wójta), a także osób z wyboru lub/i organizacji pozarządowych działających na rzecz seniorów ${ }^{21}$. Natomiast najrzadziej samorządy wybierają

19 Żeby możliwe było powołanie rady seniorów jednostki pomocniczej (sołectwa, osiedla, dzielnicy) gminy, niezbędne jest zapisanie takiej możliwości w statucie tej jednostki pomocniczej. Podjęcie uchwały wprowadzającej do statutu jednostki pomocniczej możliwość powołania rady seniorów tej jednostki nie jest regulowane nowym przepisem ustawy samorządowej, a więc następuje w trybie i na zasadach określonych dla statutów jednostek pomocniczych. Zatem w przypadku rady seniorów jednostki pomocniczej podział zadań między organami wygląda w ten sposób, że w pierwszej kolejności rada gminy upoważnia radę jednostki pomocniczej (w jej statucie) do utworzenia rady seniorów. Z kolei rada jednostki pomocniczej powołuje w drodze własnej uchwały radę seniorów i nadaje jej jednocześnie statut - B. Starczewski, Gminne rady seniorów - samorządy przekonają się do nowej instytucji? (2.12.13), http://www.samorzad.lex.pl/czytaj/-/artykul/gminne-rady-seniorow--samorzady-przekonaja-sie-do-nowej-instytucji (dostęp: 12.04.2018).

20 R. Mędrzycki, Funkcje gminnych rad seniorów, „Ruch Prawniczy, Ekonomiczny i Socjologiczny” 2017, z. 3, s. 125.

${ }^{21}$ W Toruniu do rady seniorów od 5 do 7 osób wskazuje zarówno Rada Miasta, jak i Prezydent, natomiast 7 osób pochodzi z publicznego naboru. Dodatkowo na maksymalnie 21 osób w radzie minimum połowę stanowić muszą osoby w wieku 60+ $-\$ 3.1-3.2$ Statutu Rady Seniorów Miasta Torunia (Załącznik do Uchwały nr 810/14 Rady Miasta Torunia z 26 czerwca 2014 r.); http://www.torun.pl/pl/miasto/samo- 
formułę wyborów powszechnych mieszkańców w wieku senioralnym ${ }^{22}$. W statutach określa się również m.in. podmiot odpowiedzialny za wsparcie organizacyjne (obsługę administracyjną i organizację prac rady), częstotliwość spotkań, a także obszary działania. Jednak w tej ostatniej materii zapisy dotyczące kompetencji i zadań rad seniorów mają zazwyczaj bardzo ogólny charakter (trudno z nich wnioskować, czym dokładnie powinny się one zajmować).

\section{Funkcjonowanie gminnych rad seniorów ze szczególnym uwzględnieniem województwa pomorskiego}

Do początku 2016 r. gminne rady seniorów działały w mniej niż co dziesiątej gminie w Polsce. Choć na przestrzeni kolejnego roku ich liczba znacząco wzrosła w ujęciu bezwzględnym — do 290 jednostek, to w dalszym ciągu istniały one tylko w co ósmej gminie (szczegółowe dane zamieszczono w tabeli 2).

Tabela 2. Rady seniorów w Polsce w latach 2012-2017

\begin{tabular}{c|c|c}
\hline Rok & Liczba & Odsetek gmin (\%) \\
\hline 2012 & 9 & 0,36 \\
\hline 2013 & 46 & 1,85 \\
\hline 2014 & 75 & 3 \\
\hline 2015 & 100 & 4 \\
\hline 2016 & 197 & 8 \\
\hline 2017 & 290 & 12 \\
\hline
\end{tabular}

Źródło: A. Ganeczko, Rady seniorów w Polsce: podstawa prawna i liczba, „Polityka Senioralna” 2017, nr 4, s. 5; Pełny zapis przebiegu posiedzenia Komisji Polityki Senioralnej (nr 49), Komisji Samorządu Terytorialnego i Polityki Regionalnej (nr 176), 23 listopada 2017, s. 5.

W 2014 r. najwięcej gminnych rad seniorów w układzie przestrzennym działało w województwach śląskim (19) i wielkopolskim (18), a najmniej (po trzy) w: podlaskim, lubuskim, łódzkim, świętokrzyskim i podkarpackim ${ }^{23}$. Do połowy 2016 r. na pierwsze miejsce pod względem liczebności rad seniorów wysunęło się województwo mazowieckie (41), następnie śląskie (27) i wielkopolskie (20), a najmniej było ich w łódzkim (7), warmińsko-mazurskim (8), podlaskim (9) i świętokrzyskim (10).

$\mathrm{rzad} /$ prezydent-torunia/ciala-doradcze-prezydenta/rada-seniorow-miasta-torunia; http://www.bip.torun. pl/dokumenty.php?Kod=122884 (dostęp: 14.04.2018).

22 A. Fiedotow, op. cit., s. 8.

23 Zoom na rady seniorów. Diagnoza funkcjonowania, Warszawa 2014, s. 13-14. 
Tabela 3. Rady seniorów w Polsce 2016 r. (maj) według województw

\begin{tabular}{l|c|c|c}
\hline & Liczba rad seniorów & Liczba gmin & Odsetek gmin (\%) \\
\hline Polska & $\mathbf{2 5 7}$ & $\mathbf{2 4 7 8}$ & $\mathbf{1 0 , 2}$ \\
\hline Województwo dolnośląskie & 16 & 169 & 9,5 \\
\hline Województwo kujawsko-pomorskie & 14 & 144 & 9,7 \\
\hline Województwo lubelskie & 17 & 213 & 8,0 \\
\hline Województwo lubuskie & 12 & 83 & 14,5 \\
\hline Województwo łódzkie & 7 & 177 & 4,0 \\
\hline Województwo małopolskie & 19 & 182 & 10,4 \\
\hline Województwo mazowieckie & 41 & 314 & 13,0 \\
\hline Województwo opolskie & 15 & 71 & 21,1 \\
\hline Województwo podkarpackie & 11 & 160 & 6,8 \\
\hline Województwo podlaskie & 9 & 118 & 7,6 \\
\hline Województwo pomorskie & 27 & 123 & 14,6 \\
\hline Województwo śląskie & 10 & 167 & 16,1 \\
\hline Województwo świętokrzyskie & 8 & 102 & 9,8 \\
\hline Województwo warmińsko-mazurskie & 13 & 116 & 6,9 \\
\hline Województwo wielkopolskie & 20 & 114 & 8,8 \\
\hline Województwo zachodniopomorskie & 13 & 11,4 \\
\hline
\end{tabular}

Źródło: opracowanie własne na podstawie: Informacja o sytuacji osób starszych w Polsce za rok 2015, MRPiPS, Warszawa 2016; Informacja o sytuacji osób starszych w Polsce za rok 2016, MRPiPS, Warszawa 2017.

Biorąc pod uwagę rozkład względny, a mianowicie odsetek gmin w województwach, w których funkcjonują rady seniorów (dane w tabeli 3), można dostrzec, że na tle średniej dla kraju relatywnie najwięcej mieliśmy ich w województwach: opolskim (w co piątej gminie), śląskim (co szóstej), a także pomorskim i lubuskim (w co siódmej).

Województwo pomorskie znajduje się w czołówce względnej liczby funkcjonujących rad seniorów w stosunku do liczby gmin (od lutego $2018 \mathrm{r}$. w ponad 17\% gmin). Wnikając jednak bardziej w istotę rzeczy i uwarunkowania regionalne oraz charakter działających na analizowanym obszarze rad seniorów, można zauważyć, że powstają one zdecydowanie częściej (proporcjonalnie) w gminach miejskich i w miastach na prawach powiatu - największych ośrodkach miejskich (szczegółowe dane w tabeli 4). Z jednej strony są to swego rodzaju centra gospodarcze i kulturalne, $\mathrm{z}$ drugiej - należą jednocześnie do najstarszych pod względem demograficznym. 
Tabela 4. Rady seniorów w województwie pomorskim według rodzaju gmin

\begin{tabular}{l|c}
\hline \multicolumn{1}{c|}{ Rodzaj i liczba gmin } & Rady seniorów (odsetek gmin) [\%] \\
\hline Gminy: $123 \rightarrow$ rady seniorów w 21 gminach & 17,07 \\
\hline Gminy miejskie: $19 \rightarrow 9$ rad seniorów & 47,36 \\
\hline Gminy wiejskie: $81 \rightarrow 5$ rad seniorów & 6,1 \\
\hline Gminy miejsko-wiejskie: $19 \rightarrow 3$ rady seniorów & 15,78 \\
\hline Miasta na prawach powiatu: $4 \rightarrow 4$ rady seniorów & 100 \\
\hline
\end{tabular}

Źródło: B. Bałka, Finansowanie działalności gminnych rad seniorów, materiał powielony: seminarium warsztatowe dedykowane radom seniorów w województwie pomorskim (13.12.2017), ROPS w Gdańsku; z uwzględnieniem gminnych rad seniorów utworzonych w lutym 2018 r. (w miejscowościach: Łeba, Czersk, Sopot).

Szczyt powstawania gminnych rad seniorów w województwie pomorskim przypadł na lata 2014-2015 (odpowiednio: cztery i osiem rad). Później dynamika wyhamowała w kolejnym powołano bowiem tylko trzy, a w 2017 r. ani jednej ${ }^{24}$. Dopiero na początku 2018 r. powstały trzy kolejne (w miejscowościach: Łeba, Czersk i Sopot).

$\mathrm{Z}$ analizy funkcjonowania gminnych rad seniorów w pomorskim wynika, że w zdecydowanej większości samorządów są one obecnie (pierwsza połowa 2018 r.) w trakcie pierwszej kadencji (tylko cztery w trakcie kolejnych). Ich skład osobowy waha się od 6 do 20 członków (realnie), jednak najczęściej w praktyce ich liczba mieści się w przedziale 11-15 osób. Przeważnie są one powoływane na 4-letnią kadencję lub (prawie równie często) na okres kadencji rady gminy. Czas, jaki upłynął średnio od uchwały rady gminy do powołania członków gminnej rady seniorów, oscyluje wokół 5 miesięcy - przy czym najszybciej dokonano tego w ciągu miesiąca (w Kobylnicy), a najdłużej trwało to aż 11 miesięcy (w Karsinie). Należy też zaznaczyć, że w jednej gminie uchylono uchwałę powołującą członków rady seniorów (w związku z czym realnie nie funkcjonuje) ${ }^{25}$. Dwie kolejne rady powoływane są na podstawie zarządzenia prezydentów miast (są ich organem konsultacyjno-doradczym) i w oparciu o regulamin (w Gdańsku) czy zasady działania (Gdynia). Są to więc nieco inne ciała, o czym świadczą także różnice w ich nazewnictwie (rady „do spraw Seniorów”), odgrywają jednak podobną rolę.

${ }^{24}$ W 2017 r. powstała natomiast Pomorska Rada do spraw Polityki Senioralnej jako organ konsultacyjny, opiniująco-doradczy i inicjatywny Zarządu Województwa Pomorskiego do realizacji polityki senioralnej — Uchwała nr 758/246/17 Zarządu Województwa Pomorskiego z 27 czerwca 2017 r.

25 W Kolbudach uchwałę uchylono ze względu na brak cenzusu wieku dla przedstawicieli osób starszych oraz ze względu na kontrowersje związane ze sposobem zgłaszania kandydatów (zgłoszono przedstawicieli tylko z 7 sołectw, co znaczy, że ponad połowa sołectw nie wyłoniła swojego przedstawiciela, w efekcie czego w wyborach nie wzięli również udziału zamieszkali w nich wyborcy). 


\begin{tabular}{|c|c|c|c|c|c|}
\hline 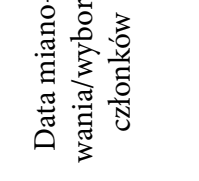 & $\begin{array}{l}\text { पें } \\
\text { पें } \\
\text { iे }\end{array}$ & $\begin{array}{l}0 \\
\stackrel{0}{1} \\
\stackrel{\leftrightarrow}{4} \\
\dot{+} \\
+\end{array}$ & 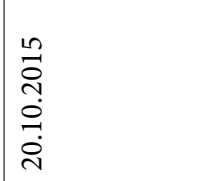 & 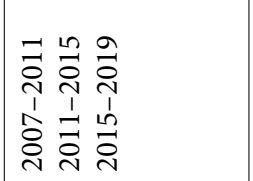 & 㐫 \\
\hline 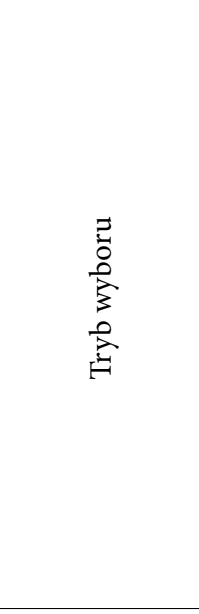 & 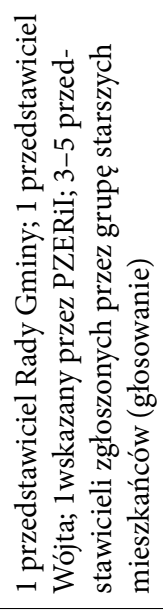 & 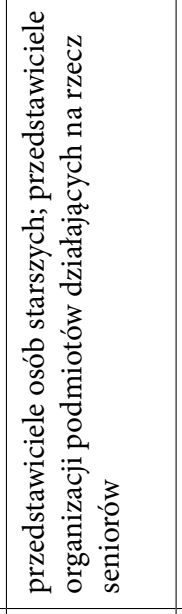 & 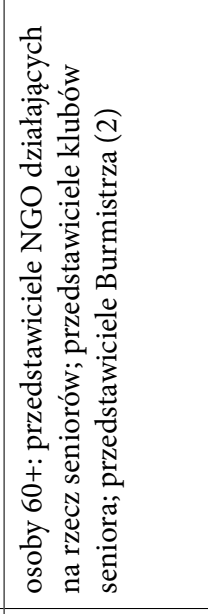 & 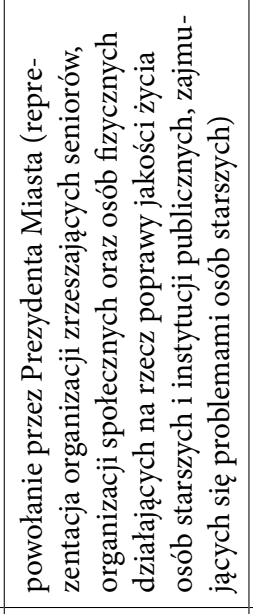 & 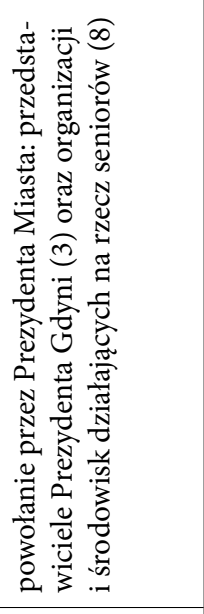 \\
\hline 今్ & 6 & $n$ & $\cong$ & $\cong$ & $=$ \\
\hline 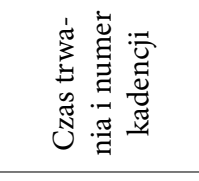 & $+\begin{array}{r}\stackrel{\overrightarrow{\tilde{I}}}{=} \\
\end{array}$ & in & 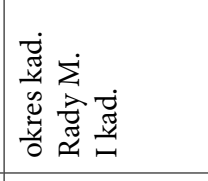 & $\begin{array}{r}\stackrel{\vec{E}}{\mathbb{E}} \\
+\end{array}$ & $\begin{array}{r}\stackrel{\vec{E}}{\mathbb{E}} \\
+ \\
\end{array}$ \\
\hline 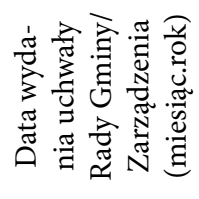 & 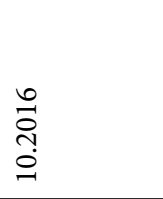 & 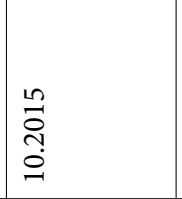 & 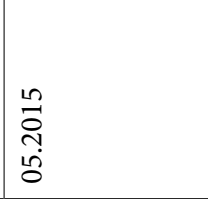 & 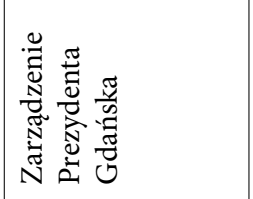 & 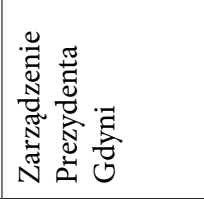 \\
\hline & 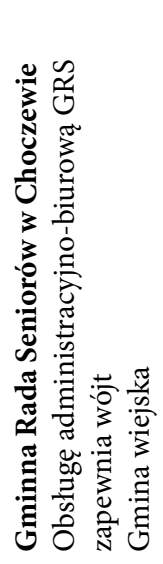 & 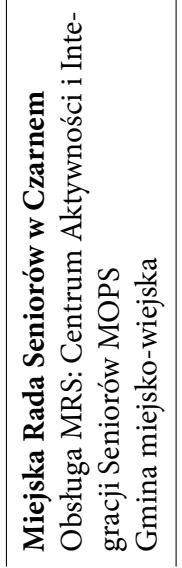 & 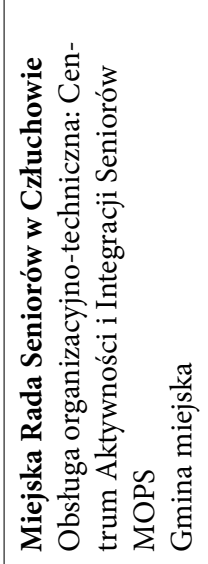 & 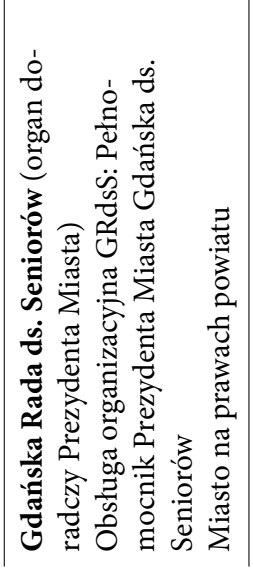 & 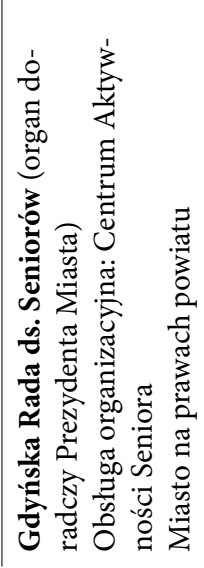 \\
\hline
\end{tabular}




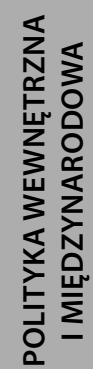

\begin{tabular}{|c|c|c|c|c|}
\hline 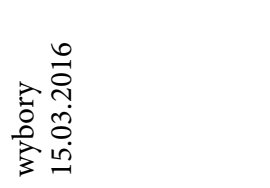 & $\begin{array}{l}0 \\
\stackrel{0}{0} \\
i \\
0 \\
0\end{array}$ & 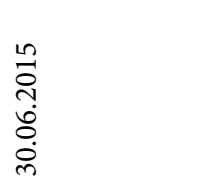 & 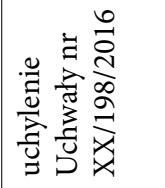 & $\begin{array}{ll}m & n \\
0 & 0 \\
& \text { ñ } \\
0 & 0\end{array}$ \\
\hline 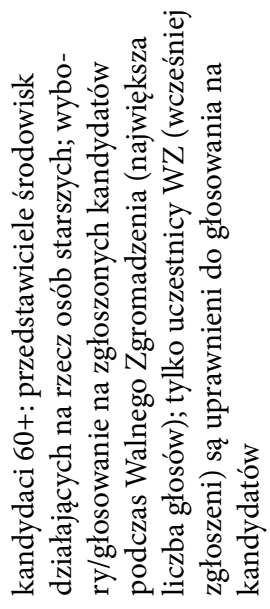 & 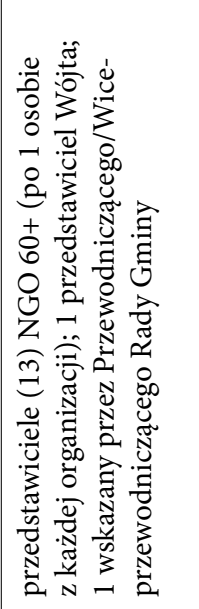 & 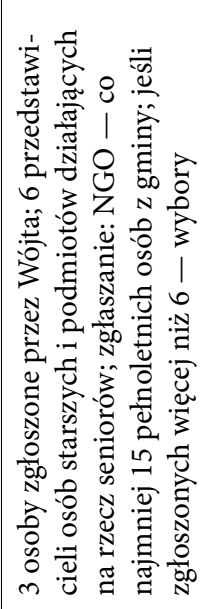 & 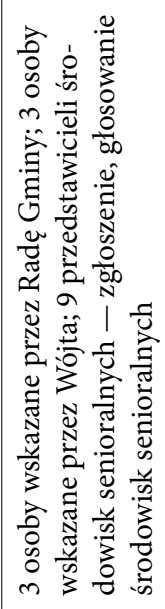 & 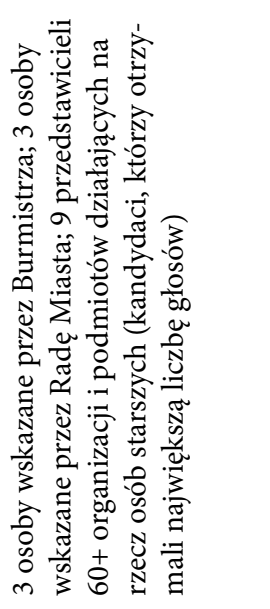 \\
\hline$a$ & $\stackrel{2}{=}$ & $a$ & $\stackrel{2}{2}$ & 10 \\
\hline$\sim$ & 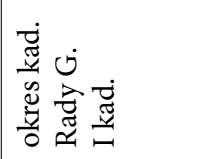 & 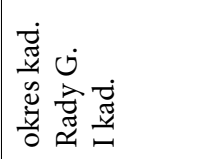 & 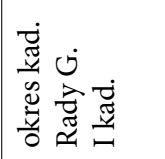 & 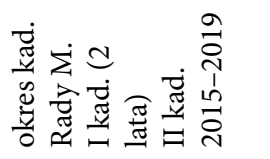 \\
\hline 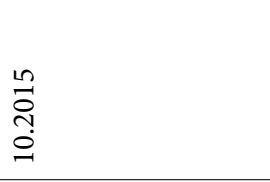 & 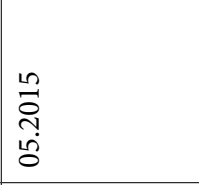 & 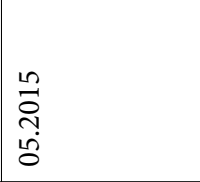 & 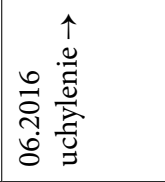 & 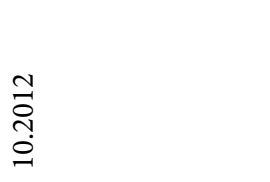 \\
\hline 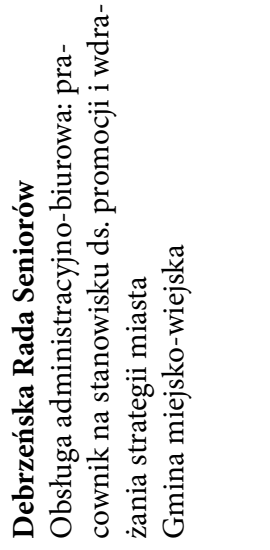 & 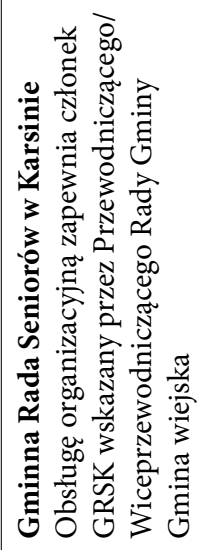 & 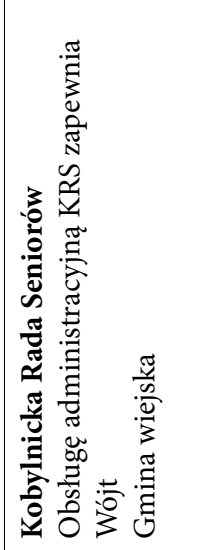 & 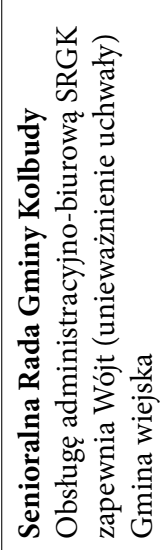 & 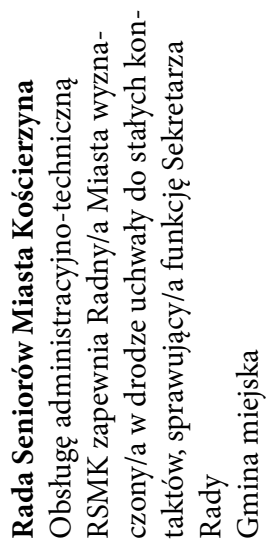 \\
\hline
\end{tabular}




\begin{tabular}{|c|c|c|c|c|}
\hline the & 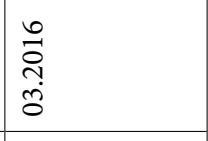 & $\stackrel{n}{\stackrel{2}{\grave{3}}}$ & 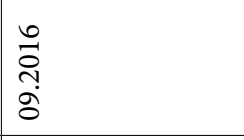 & 容 \\
\hline 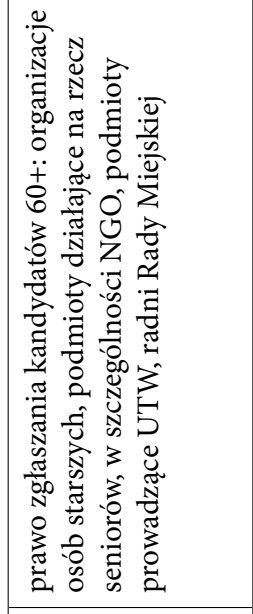 & 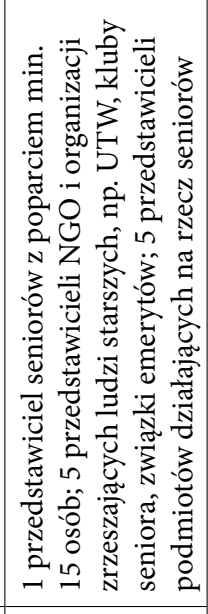 & 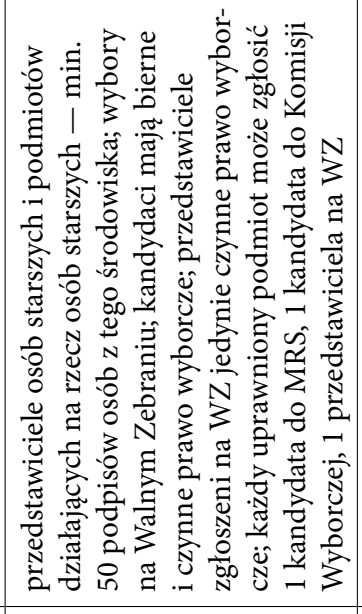 & 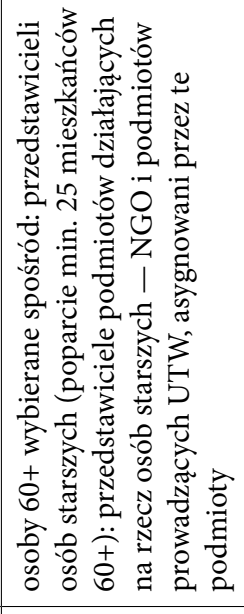 & 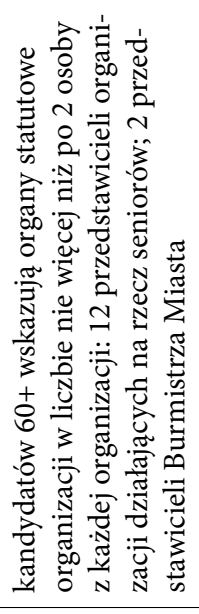 \\
\hline ì & $\Rightarrow$ & $\sigma$ & $a$ & \pm \\
\hline 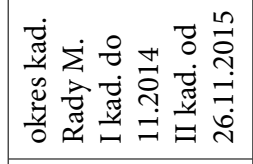 & $\begin{array}{l}\text { 离 } \\
+\end{array}$ & $\begin{array}{r}\text { 胥 } \\
+\end{array}$ & $\begin{array}{r}\text { 离 } \\
+ \\
\end{array}$ & 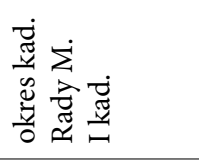 \\
\hline ti & $\begin{array}{l}n \\
\stackrel{2}{3} \\
\\
\end{array}$ & \begin{tabular}{|l} 
na \\
d. \\
d.
\end{tabular} & 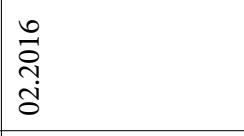 & $\begin{array}{l}\underset{0}{0} \\
\substack{1 \\
0} \\
\end{array}$ \\
\hline 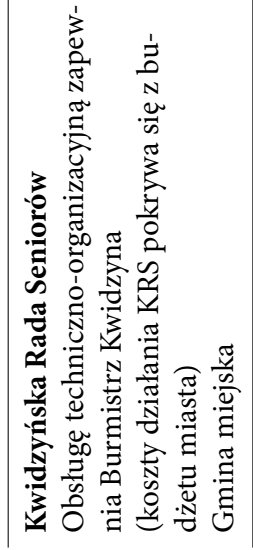 & 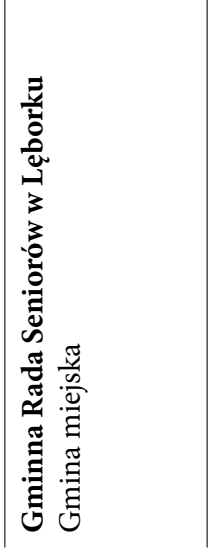 & 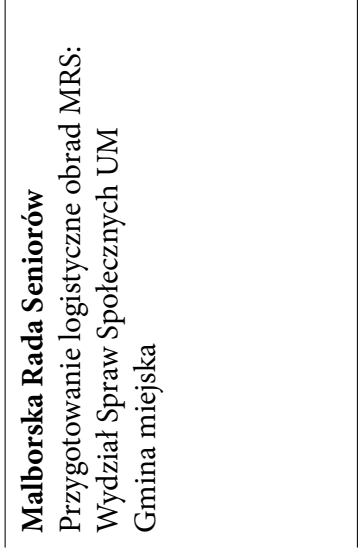 & 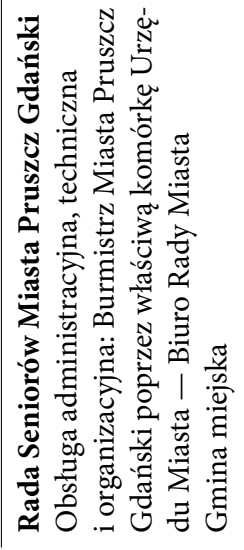 & 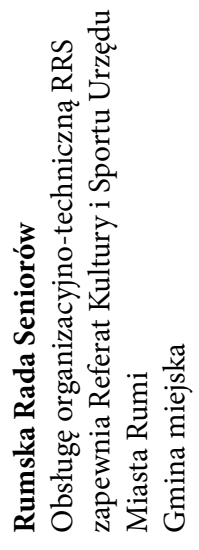 \\
\hline
\end{tabular}




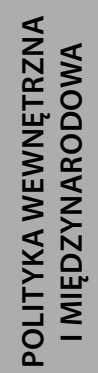

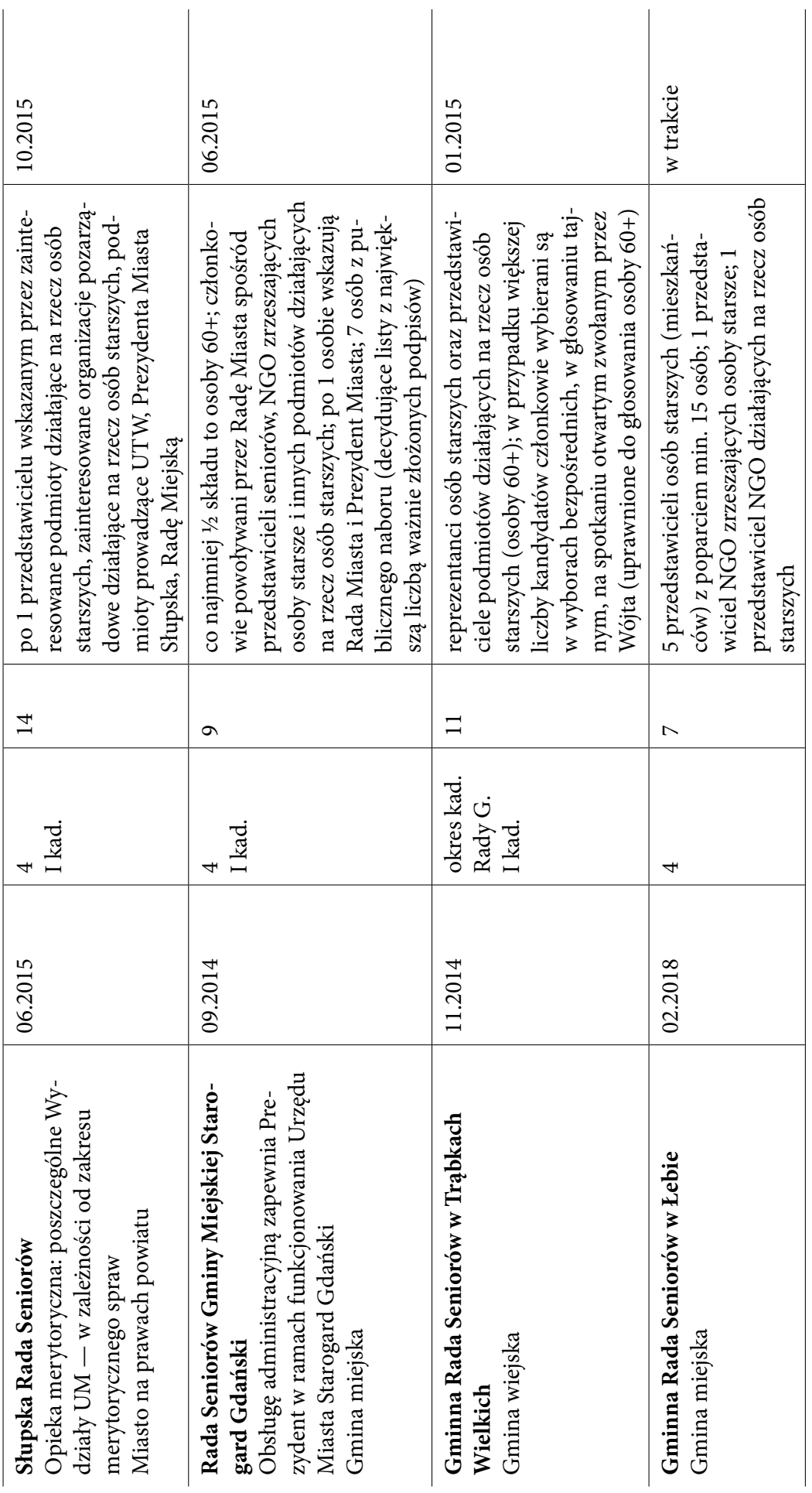




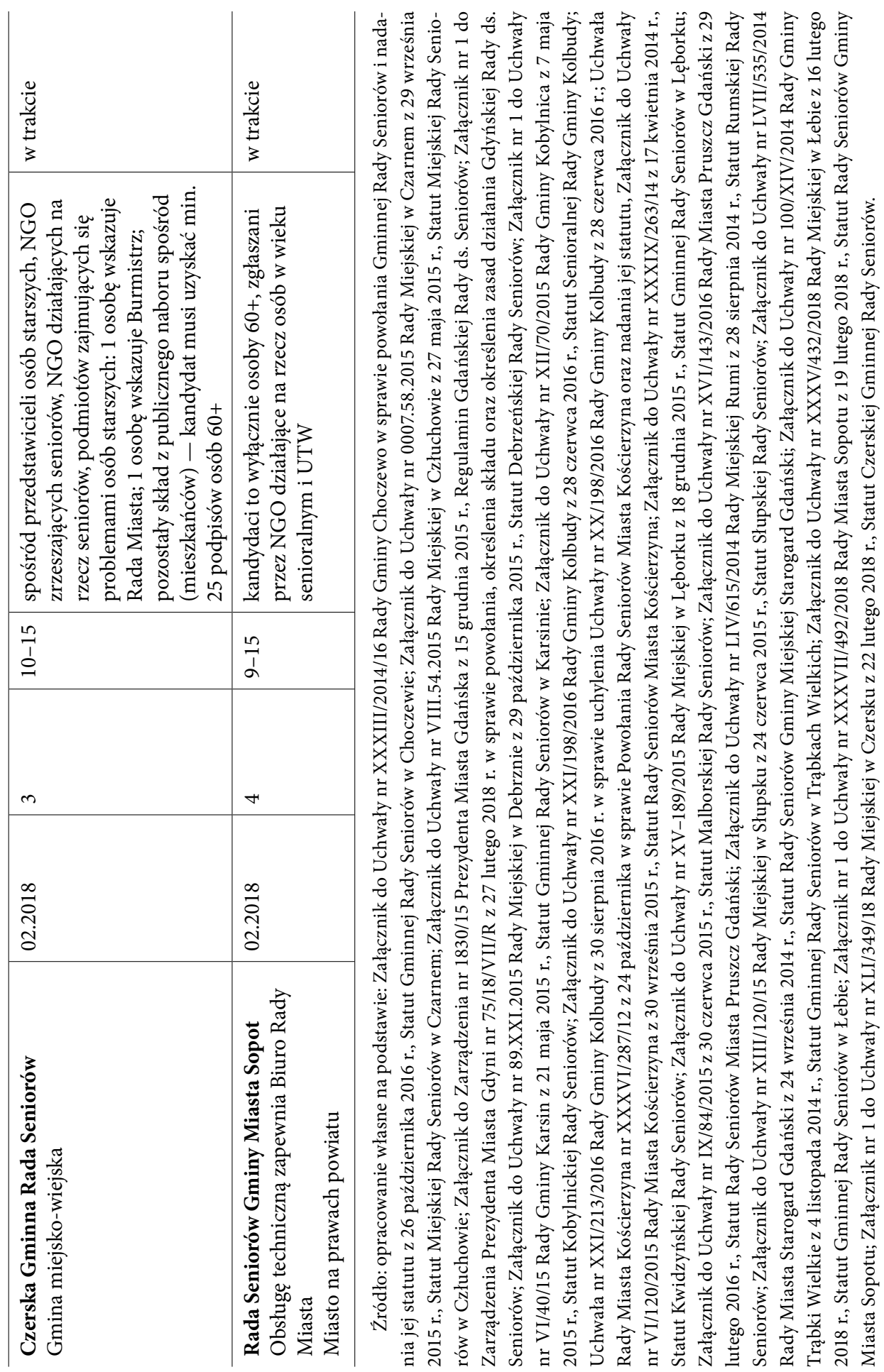


Pewną prawidłowością jest, że (w większości przypadków) w skład gminnych rad seniorów w województwie pomorskim wchodzą przedstawiciele organów uchwałodawczych (rad miejskich, gminnych), wykonawczych (prezydenta, burmistrza, wójta), a także przedstawiciele organizacji senioralnych, organizacji działających na ich rzecz i reprezentanci starszych mieszkańców. W pięciu miejscowościach (zgodnie ze statutem) muszą być to osoby w wieku 60+ (w Debrznie, Kwidzynie, Rumi i Sopocie - wskazywane są one przez organizacje pozarządowe, w Trąbkach Wielkich - tylko osoby $60+$ mają $w$ tej sprawie zarówno bierne, jak i czynne prawo wyboru), inne są nieco bardziej liberalne w tym względzie i określają, że co najmniej połowę składu rady seniorów muszą stanowić osoby 60+ (Starogard Gdański). W niektórych miejscowościach dla osób starających się o powołanie do rady seniorów (z wyboru) istnieje też konieczność poparcia (zebrania podpisów) czy zgłoszenia kandydatów przez grupę mieszkańców gminy (np. w Kobylnicy na 9 osób -6 pochodzi z wyborów, a zgłoszone muszą one być przez minimum 15 osób z gminy lub stowarzyszenie; w Lęborku jeden przedstawiciel seniorów z poparciem co najmniej 15 osób; w Malborku wymagane jest 50 podpisów; w Pruszczu Gdańskim minimum 25 podpisów mieszkańców $60+$ ).

$\mathrm{Z}$ analizy statutów rad seniorów wynika, że ich postanowienia, uchwały, decyzje, wnioski, stanowiska, ustalenia lub opinie i postulaty zapadają zwykłą większością głosów. Częstotliwość spotkań, prawie we wszystkich przypadkach, jest praktycznie taka sama i odbywają się one „nie rzadziej niż raz na kwartał” lub „co najmniej raz na kwartał”. $\mathrm{W}$ dwóch przypadkach (Lębork i Łeba) spotkania są zwoływane z inicjatywy własnej przewodniczącego lub na wniosek — odpowiednio - co najmniej trzech lub dwóch członków rady seniorów, w kolejnym (Trąbki Wielkie) oprócz trybu kwartalnego dopuszcza się ewentualność spotkania raz na pół roku. $Z$ analizy wynika, że realnie senioralni radni najczęściej spotykają w Malborku (co miesiąc) i w Słupsku (co 2 miesiące) ${ }^{26}$.

Co prawda gminną radę seniorów powołuje rada gminy, ale to po stronie organu wykonawczego znajduje się dalsze wsparcie organizacyjne rady seniorów (np. zapewnienie lokalu) oraz ewentualne finansowanie jej działalności. Spośród analizowanych przypadków w zdecydowanej większości zarówno obsługę administracyjno-biurową, jak i organizację samych spotkań zapewnia organ wykonawczy za pośrednictwem odpowiednich komórek (wydziałów, referatów) w strukturze poszczególnych urzędów gmin bądź określony pracownik urzędu.

\section{Obszary zainteresowania i wybrane inicjatywy gminnych rad seniorów}

Trudno doszukiwać się w ustawie o samorządzie gminnym ścisłego katalogu konkretnych kwestii, co do których rady seniorów mogą wychodzić z własną inicjatywą lub wyrażać swoje opinie. W tym kontekście twierdzi się, że brak precyzyjnie spisanych kompetencji

26 Częstotliwość spotkań na podstawie analizy protokołów z obrad Malborskiej Rady Seniorów (dostępne: http://bip.malbork.pl/Article/id,353.html) i Słupskiej Rady Seniorów (dostępne: http://www.slupsk. $\mathrm{pl} /$ seniorzy/slupska-rada-seniorow/). 
i zadań rad seniorów jest jedną z największych formalnych barier $\mathrm{w}$ ich funkcjonowaniu (oprócz braku wyodrębnionego budżetu) ${ }^{27}$. $\mathrm{Z}$ analizy statutów rad seniorów wynika, że wśród zadań i obszarów ich działalności najczęściej pojawiają się zapisy dotyczące monitorowania potrzeb osób starszych, działań w kierunku ich aktywizacji i integracji społecznej, a także współpracy z władzami i organizacjami pozarządowymi na rzecz lepszych warunków życia itp. Zatem jest to wiele spraw oscylujących zarówno wokół pomocy społecznej i ochrony zdrowia, jak i transportu publicznego, edukacji oraz kultury i innych - jeśli dotyczą ludzi starszych.

Można stwierdzić, że w praktyce rady seniorów w województwie pomorskim zajmują się w dużej mierze koordynacją działań organizacji pozarządowych na rzecz ludzi starszych. Pozwala to m.in na koncentrację potencjału (nierzadko kilku podmiotów) na wspólnym celu czy wypracowaniu stanowiska i tym samym na zwiększeniu szans na realizację. Mają one również istotny głos doradczy w sprawach systemowych, takich jak powstawanie dziennych domów pobytu, wdrażanie teleopieki ${ }^{28}$ czy przepływ informa$\mathrm{cji}^{29}$. Podobnie do rad seniorów w innych miejscach w kraju, również te w pomorskim wychodzą z własnymi propozycjami, jak np.: utworzenie (i aktualizacja) zakładki dla seniorów na stronie gminy, koncepcje centrum aktywnego seniora, przyznawanie wyróżnień (dla osób fizycznych, firm, organizacji) za działania na rzecz osób starszych w danej gminie, organizacja dni seniora ${ }^{30}$. Ich inicjatywy są jednak uzależnione, po pierwsze, od przychylności władz gminy, a po drugie — od środków finansowych, które generują. W tym miejscu należy dodać, że rady seniorów nie mając podmiotowości prawnej (w odróżnieniu od stowarzyszeń czy fundacji), nie mogą być stroną umów przewidujących zobowiązania finansowe, $\mathrm{w}$ związku z czym w praktyce nieocenione okazuje się wsparcie lokalnych organizacji pozarządowych. Niektórym samorządom lokalnym udaje się jednak finansować wybrane koszty działania rady seniorów (jak np. w Kwidzynie czy w Słupsku) ${ }^{31}$, jednak nie ma tutaj prostych możliwości zrefundowania np. kosztów delegacji czy udziału w konferencjach.

Na szczególne potraktowanie zasługuje również rola rzecznicza odgrywana przez gminne rady seniorów. Obok ich obrad jedną z form pracy rad seniorów są bowiem regularne dyżury otwarte dla starszych mieszkańców gminy. W trakcie tego typu dyżurów do senioralnych radnych przychodzą zarówno osoby poszukujące pomocy w rozwiązaniu nurtujących je problemów, jak i zgłaszające pomysły oraz propozycje (spotkań, działań

27 Zoom na rady seniorów..., s. 8.

28 Gminna Rada Seniorów w Lęborku opiniowała burmistrzowi ofertę i program zaproponowany ze strony operatora teleopieki - Protokół nr 2 z posiedzenia GRSL z 26.04.2016, http://www.lebork.pl/files/ download/5559/Protokol-2.pdf (dostęp: 14.04.2018).

29 Protokół ze spotkania Malborskiej Rady Seniorów z 4.01.2017, http://bip.malbork.pl/Article/get/ id,21723.html (dostęp: 14.04.2018).

30 Protokoły ze spotkań Malborskiej Rady Seniorów z 20.04.2017 i 20.06.2017, http://bip.malbork.pl/ Article/get/id,21723.html (dostęp: 14.04.2018).

31 Słupska Rada Seniorów w 2017 r. otrzymała do „Zagospodarowania” budżet w wysokości 20000 zł (środki w dyspozycji Wydziału Zdrowia i Spraw Społecznych Urzędu Miasta). Sfinansowano z nich m.in.: kopertę życia, imprezę dla seniorów, materiały promocyjne i współfinansowano informator dla seniorów - Sprawozdanie roczne Słupskiej Rady Seniorów za 2017 r., Słupsk 2.01 .2018 r., http://www.slupsk.pl/ seniorzy/slupska-rada-seniorow/ (dostęp: 14.04.2018). 
i imprez). Często takie dyżury pełnią też funkcję informacyjną, dzięki czemu starsi mieszkańcy gminy są kierowani do odpowiednich instytucji czy osób. Jest to zatem przekazywanie wiedzy o dostępnych uprawnieniach i możliwościach. Przykładowo: w Słupsku i Pruszczu Gdańskim poszczególni członkowie rady seniorów regularnie raz w miesiącu pełnią dwugodzinne dyżury, które mają charakter konsultacyjno-informacyjny i można zwrócić się do nich z różnymi problemami.

\section{Podsumowanie}

Gminne rady seniorów w Polsce powstają od 2013 r. na mocy nowelizacji ustawy o samorządzie gminnym. Na przestrzeni czterech lat powstało ich ponad 290, statystycznie funkcjonują zatem w co ósmej gminie w kraju. Z analizy funkcjonowania rad seniorów w województwie pomorskim wynika, że działają one w 17\% samorządów, jednak stosunkowo najwięcej powstało ich $\mathrm{w}$ gminach o charakterze miejskim i miastach na prawach powiatu. W praktyce członkami gmin seniorów stają się zarówno przedstawiciele seniorów, organizacji działających na ich rzecz, jak i reprezentanci gminy. W kilku przypadkach radnymi mogą zostać wyłącznie osoby w wieku 60+. Liczba członków gminnych rad seniorów najczęściej zawiera się w przedziale 11-15 osób, które są powoływane najczęściej na 4 lata (lub na okres kadencji rady gminy).

Podczas analizy funkcjonowania gminnych rad seniorów w województwie pomorskim na tle kraju nasuwa się kilka refleksji natury ogólnej. Po pierwsze, należy wskazać to, że ich uprawnienia nie mają lub nie muszą mieć mocy wiążącej. Pojawiają się też głosy, że są one powoływane w niedemokratyczny sposób - reprezentują organizacje senioralne o największej sile przebicia. Po drugie, władze gmin mają do czynienia z instytucjami, które w zorganizowany systemowy sposób próbują aktywizować starszych obywateli i mogą przyczyniać się do wzrostu ich zaangażowania w życie lokalne i w sferę obywatelskiej aktywności. Przykłady przedsięwzięć pokazują, że gminne rady seniorów mają do tego potencjał. Ważne jest również to, że władze gminy mogą wykorzystywać te instytucje jako źródło informacji o oczekiwaniach i potrzebach osób starszych. Nie do przecenienia jest również rola rzecznicza rad seniorów - regularne, otwarte dla starszych mieszkańców dyżury, podczas których udzielane są porady czy zgłaszane inicjatywy. Za pośrednictwem rad seniorów starsi obywatele mogą mieć większy wpływ na decyzje władz samorządowych, a te mogą podejmować je w związku $\mathrm{z}$ artykułowanymi oczekiwaniami - co dla polityków jest szczególnie istotne, ponieważ seniorzy są cenionym i rosnącym w siłę liczebną elektoratem.

\section{Bibliografia}

Abłażewicz-Górnicka U., Krakowska E., Partycypacja obywatelska, [w:] Seniorzypartycypuja, red. K. Sztop-Rutkowska, Laboratorium Badań i Działań Społecznych SOCLAB, Białystok 2014.

Augustyniak M. et al., Gminne rady seniorów - wykładnia przepisów i efekty ich stosowania. Wzory i schematy działań, Wolters Kluwer, Warszawa 2016. 
Bałka B., Finansowanie działalności gminnych rad seniorów, materiał powielony: seminarium warsztatowe dedykowane radom seniorów w województwie pomorskim (13.12.2017), ROPS w Gdańsku.

Buczyńska A., Buczyński P., Miejski model aktywności społecznej seniorów, Regionalne Centrum Wolontariatu, Gdańsk 2013.

Czapiński J., Błędowski P., Aktywność społeczna osób starszych w kontekście percepcji Polaków. Diagnoza społeczna 2013. Raport tematyczny, Centrum Rozwoju Zasobów Ludzkich, Warszawa 2014.

Czekanowski P., Załęcki J., Brosz M., Gdańska starość. Portret socjologiczny mieszkańców Gdańska w wieku 65+, Gdańsk 2013.

Fiedotow A., ABC Rad Seniorów, „Polityka Senioralna” 2017, nr 4.

Ganeczko A., Rady seniorów w Polsce: Podstawa prawna i liczba, „Polityka Senioralna” 2017, nr 4.

Grotowska S., Seniorzy w przestrzeni publicznej: kapitał społeczny uczestników wspólnot, ruchów i stowarzyszeń katolickich, Zakład Wydawniczy „Nomos”, Kraków 2011.

Informacja o sytuacji osób starszych w Polsce za rok 2015, MRPiPS, Warszawa 2016.

Informacja o sytuacji osób starszych w Polsce za rok 2016, MRPiPS, Warszawa 2017.

Mędrzycki R., Funkcje gminnych rad seniorów, „Ruch Prawniczy, Ekonomiczny i Socjologiczny” 2017, z. 3.

Olech A., Wprowadzenie, [w:] Dyktat czy uczestnictwo? Diagnoza partycypacji publicznej w Polsce, red. A. Olech, ISP, Warszawa 2012.

Pełny zapis przebiegu posiedzenia Komisji Polityki Senioralnej (nr 49), Komisji Samorządu Terytorialnego i Polityki Regionalnej (nr 176), 23 listopada 2017.

Starczewski B., Gminne rady seniorów - samorządy przekonają się do nowej instytucji? (2.12.13), http:// www.samorzad.lex.pl/czytaj/-/artykul/gminne-rady-seniorow--samorzady-przekonaja-sie-do-nowejinstytucji (dostęp: 12.04.2018).

Starzyk K., Co gminom po radach seniorów, co seniorom po radach?, „Instytut Idei” 2014, nr 7, s. 76-79.

Uchwała nr 758/246/17 Zarządu Województwa Pomorskiego z 27 czerwca 2017 r. w sprawie powołania Pomorskiej Rady do spraw Polityki Senioralnej.

Ustawa z 8 marca 1990 r. o samorządzie gminnym, t.j. Dz.U. z 2017, poz. 1875.

Ustawa z 21 października 2013 r. o zmianie ustawy o samorządzie gminnym, Dz.U. z 2013, poz. 1318.

Ustawa z 26 października 2015 r. o osobach starszych, Dz.U. z 2015, poz. 1705.

Weryński P., Wzory uczestnictwa obywatelskiego Polaków, IFiS PAN, Warszawa 2010.

Założenia Dtugofalowej Polityki Senioralnej w Polsce 2014-2020, załącznik do uchwały nr 238 Rady Ministrów z 24 grudnia 2013 r., M.P. z 4 lutego (poz. 118).

Zoom na rady seniorów. Diagnoza funkcjonowania, Towarzystwo Inicjatyw Twórczych „ę, Pracownia Badań i Innowacji Społecznych „Stocznia”, Warszawa 2014.

\section{Municipal senior citizens councils from the local senior policy perspective}

Keywords: senior policy, municipal senior citizens councils

\section{Summary}

The article provides an analysis regarding the creation, organization and functioning of the municipal senior citizens councils in Poland - especially in Pomorskie province. The municipal senior councils are comparatively new entities and are heading towards higher degree elderly people participation in self-government decisions. Thanks to the possibilities for activation elderly people, they hope and will expect to have more influence to meet their needs. 